\title{
Dopamine Activates Masculine Sexual Behavior Independent of the Estrogen Receptor $\alpha$
}

\author{
Scott R. Wersinger and Emilie F. Rissman \\ University of Virginia, Department of Biology, Charlottesville, Virginia 22903
}

\begin{abstract}
Estrogen receptor $\alpha(\mathrm{ER} \alpha)$ is believed to be a critical part of the regulatory processes involved in normal reproduction and sexual behavior. However, in this study we show the ER $\alpha$ is not required for display of masculine sexual behavior. Male and female, $\mathrm{ER} \alpha$ knock-out (ER $\alpha \mathrm{KO}$ ) and wild-type mice were gonadectomized and implanted with testosterone. Sexual behavior and social preferences were tested after injection of the dopamine agonist, apomorphine (APO), or vehicle. All wild-type mice showed normal masculine behavior, including mounts and pelvic thrusts in females, and ejaculation in males. In agreement with past reports, $\mathrm{ER} \alpha \mathrm{KO}$ mice, given vehicle, failed to show mating behavior. Yet, ER $\alpha \mathrm{KO}$ males given APO showed mas-
\end{abstract}

An estrogen receptor (ER) is thought to be essential for sexual differentiation of the hypothalamic-pituitary-gonad (HPG) axis (Baum, 1979; Goy and McEwen, 1980; Tobet and Fox, 1992; McCarthy, 1994). Gonads of perinatal males secrete androgens that, after aromatization to estrogen, activate an ER to masculinize neural circuits (Abdelgadir et al., 1994). In addition, androgen has been shown to activate masculine behavior, in part, via the same sequence of events, aromatization, and activation of an ER (Meisel and Sachs, 1994; Vagell and McGinnis, 1997). According to this theory, $\mathrm{ER} \alpha$ knock-out ( $\mathrm{ER} \alpha \mathrm{KO}$ ) mice should be demasculinized by virtue of the lack of functional ER $\alpha$ during development, moreover, $\mathrm{ER} \alpha \mathrm{KO}$ males and females are unable to respond to many of the actions of estradiol $\left(\mathrm{E}_{2}\right)$ in adulthood. In agreement with this theory, $\mathrm{ER} \alpha \mathrm{KO}$ males fail to display normal masculine sexual behavior (Wersinger et al., 1997). Also, ER $\alpha$ KO females do not show normal female-typical behavior, nor do they display masculine behavior under the appropriate hormone and testing conditions (Rissman et al., 1997; Wersinger et al., 1997). Because $\mathrm{ER} \alpha \mathrm{KO}$ mice lack a functional $\mathrm{ER} \alpha$ both during development and adulthood, we cannot assess the role of this receptor on organization versus activation of behavior. This fact, and the discovery of a second ER, the ER $\beta$ (Kuiper et al., 1996; Tremblay et al., 1997), opens the possibility that another ER may act to organize and/or activate the HPG axis and/or neural behavioral circuits.

In adult males, it is well documented that testosterone $(\mathrm{T})$ acts as a permissive hormone, and a basal level is needed to stimulate

Received Nov. 11, 1999; revised Feb. 16, 2000; accepted March 15, 2000.

This work was supported by National Institutes of Health Grants R01 MH57759 and K02 MH01349 (E.F.R.) and National Research Service Award NS10444 (S.R.W.). We thank Aileen Wills, Savera Shetty, Elka Scordalakes, Susan Doyle, and Jennifer Temple for technical assistance and Wilson McIvor for his assistance with the HPLC. We are also indebted to Dr. Dennis Lubahn for providing us with breeders to establish our $\mathrm{ER} \alpha \mathrm{KO}$ mouse colony.

Correspondence should be addressed to Dr. E. F. Rissman, Gilmer Hall, Department of Biology, University of Virginia, Charlottesville, VA 22903. E-mail: rissman@virginia.edu.

Copyright (C) 2000 Society for Neuroscience $0270-6474 / 00 / 204248-07 \$ 15.00 / 0$ culine copulatory behavior and chemoinvestigatory behavior directed at females. ER $\alpha \mathrm{KO}$ females, treated with APO, mounted and thrusted when tested with receptive females. HPLC revealed that wild-type and $\mathrm{ER} \alpha \mathrm{KO}$ mice had equivalent catecholamine content in brain regions associated with masculine sexual behavior. These data show that the $\mathrm{ER} \alpha$ is not essential during development or adulthood for the expression of masculine sexual behavior in mice. Moreover, dopamine can activate sexual behavior via a mechanism that either acts on an $\mathrm{ER}$ other than $\mathrm{ER} \alpha$ or via an estrogen-independent pathway.

Key words: nongenomic receptors; membrane steroid receptors; sexual behavior; sex dimorphism; transgenic mouse; ER $\beta$

sexual behavior (Meisel and Sachs, 1994). However, in many animals male sexual behavior requires weeks, and in some cases longer, to extinguish after castration (Crews, 1983; Meisel and Sachs, 1994). One explanation for this delay is that some aspects of masculine sexual behavior can be maintained in a steroidindependent manner. For example, sexually experienced castrated rats treated with the dopamine agonist apomorphine (APO) months after surgery, display elevated levels of copulatory behavior (Scaletta and Hull, 1990). The relationship between mating behavior and dopamine (DA) has been well studied in male rats. These data suggest that DA release in the medial preoptic area (MPOA) is essential for activation of adult male sexual behavior (Hull et al., 1997). Treatment of pregnant rats with either DA agonists or antagonists produced a decline in the masculine sexual behavior of their male offspring (Hull et al., 1984). Thus, DA could also play a role in the development of masculine sexual behavior.

Here we tested the hypothesis that $\operatorname{ER} \alpha$ is not essential for the organization of masculine sexual behavior. We predicted that DA could induce masculine sexual behavior in an ER $\alpha$-independent manner. If $\mathrm{ER} \alpha$ is absolutely required for the establishment of the neural circuits that dictate adult masculine behaviors, then adult treatment with APO should be unable to correct the behavioral deficits seen in $\mathrm{ER} \alpha \mathrm{KO}$ mice. Alternatively if the function of $\mathrm{ER} \alpha$ is to regulate production and/or release of DA, which in turn activates copulatory behavior, treatment of adults with APO should reinstate masculine sexual behavior in $\mathrm{ER} \alpha \mathrm{KO}$ mice. We tested this hypothesis by giving systemic APO to gonadectomized wild-type and $\mathrm{ER} \alpha \mathrm{KO}$ mice receiving a concurrent low dose of T. To quantify basal levels of dopamine, its metabolites, and other catecholamines in wild-type and $\mathrm{ER} \alpha \mathrm{KO}$ mouse brains we used HPLC.

\section{MATERIALS AND METHODS}

Animals. We produced subjects by breeding pairs of mice that were heterozygotic for the ER $\alpha$ gene disruption (Lubahn et al., 1993). Dr. Dennis Lubahn (University of Missouri) generously provided us with the 
original breeders to set up our colony. We genotype the offspring by PCR analysis of tail DNA (a modification of methods in Lubahn et al., 1993). Wild-type and $\mathrm{ER} \alpha \mathrm{KO}$ littermates are of the same genetic mixed background $(129 / \mathrm{J} / \mathrm{C} 57 \mathrm{BL} / 6 \mathrm{~J})$. When these studies were conducted, our colony was in the seventh generation of backcrosses into the C57BL/6J background. Mice for these studies ( $n=40$ males; $n=39$ females) were weaned at $20 \mathrm{~d}$ of age, housed singly, and maintained on a $12 \mathrm{hr}$ light/dark photoperiod (lights off at 1:00 P.M. EDT). Food (Purina mouse chow 5001) and water were available ad libitum.

Surgery. Between the ages of 65 and $75 \mathrm{~d}$, each mouse was gonadectomized. General anesthesia (xylazine100 $\mathrm{mg} / \mathrm{kg}$ and ketamine $10 \mathrm{mg} /$ $\mathrm{kg}$ ) was given intraperitoneally. At the time of gonadectomy each mouse received a subcutaneous SILASTIC (Dow Corning) implant [outer diameter (o.d.); $2.16 \mathrm{~mm}$; inner diameter (i.d.) $1.02 \mathrm{~mm}$ ] filled with $\mathrm{T}(5$ $\mathrm{mm}$ of steroid, diluted with cholesterol 1:1). Implants were placed under the skin between the shoulder blades. For the sexual behavior and preference tests stimulus, females were required. To insure receptivity in behavior tests, heterozygotic females (produced by the $\mathrm{ER} \alpha \mathrm{KO}$ colony) were ovariectomized, and each received a SILASTIC implant (o.d., 3.18 $\mathrm{mm}$; i.d., $1.96 \mathrm{~mm})$ containing $17 \beta$ estradiol in sesame oil $(50 \mu \mathrm{g} / 0.025$ $\mathrm{ml}$ ). Three to $5 \mathrm{hr}$ before sex tests, females were injected with progesterone $(500 \mu \mathrm{g}$ in $0.025 \mathrm{ml}$ sesame oil, s.c.). Just before use females were screened for receptivity by placing them with a stud male.

Social exposure. After at least 1 week of recovery each animal was given a series of social experiences with gonad-intact, heterozygous male and female mice. During each exposure, the stimulus animals were individually placed in the subject's home cage for $2 \mathrm{~min}$. The order of presentation of the stimulus mice was alternated with each exposure. Each subject interacted with both a male and a female daily, five times over a $7 \mathrm{~d}$ period.

Drug treatment. Each subject was randomly assigned to receive either vehicle $(0.2 \%$ ascorbic acid) or APO (5 $\mu \mathrm{g}$ in $0.1 \mathrm{cc}$, i.p.) during the duration of the testing period. Our dose $(80-100 \mu \mathrm{g} / \mathrm{kg}$ body weight) of APO was based on Scaletta and Hull (1990) and pilot experiments in our lab (our unpublished observations). We did not observe any stereotypic DA-induced behaviors in animals receiving this treatment. On each testing day the mouse was injected with the assigned solution and returned to its home cage.

Sex behavior tests. Ten minutes after injection, the subject was placed into a neutral Plexiglas testing cage $(18 \times 30 \mathrm{~cm})$ on a mirror stand along with a receptive stimulus female. For males, the latency to and number of mounts, mount bouts, thrusts, intromissions, and ejaculations were recorded. For female subjects, we recorded the latency to and numbers of, mounts, mount bouts, and mounts with thrusts. If the subject mounted and remained on top of the stimulus female displaying one or multiple thrusts, we recorded this event as a single mount bout. The tests were 30-min-long and given during the dark phase of the light cycle (8:00 P.M. to 1:00 A.M.). Red lights were used for illumination. Each male was tested until an ejaculation was observed or he had had a total of three tests. Females were tested until they displayed mounts and thrusts or a maximum of three tests. Observers were blind to genotype and drug treatments. Tests were given every 2-3 d.

Preference test. The preference tests were conducted between 1:00 and 8:00 P.M. under red light illumination. The test box was a large, Plexiglas cage with three chambers, two equal-size end areas $(31.5 \times 25.5 \mathrm{~cm}$ each), and a smaller $(10.5 \times 25.5 \mathrm{~cm})$ neutral section between them (Wersinger and Rissman, 2000). The stimulus animals were anesthetized with xylazine/ketamine and then placed in the end compartments. During the $10 \mathrm{~min}$ preference test an intact male was placed in one end compartment and an ovariectomized, estrogen-implanted, female in the other. The subjects were injected with either APO or vehicle and then placed in their home cage. Ten minutes later they were placed in the neutral compartment of the testing chamber. The number of entrances and the time spent in each compartment were recorded. In addition, the amount of time the subject spent sniffing the body of each stimulus animal was recorded. The test box was carefully cleaned with alcohol between trials, and the level of anesthesia for the stimulus mice was checked.

Brain collection and tissue preparation. Ten days after the preference test, each subject was deeply anesthetized with xylazine/ketamine and decapitated. The brains were removed, frozen on dry ice, and stored at $-70^{\circ} \mathrm{C}$ until dissection. Tissue from the accessory olfactory bulb (AOB), nucleus accumbens, striatum (the caudate putamen), MPOA, medial amygdala (MA), and the substantia nigra was collected. A $200 \mu \mathrm{m}$ section was cut at a standard rostrocaudal level for each area. Next, tissue was
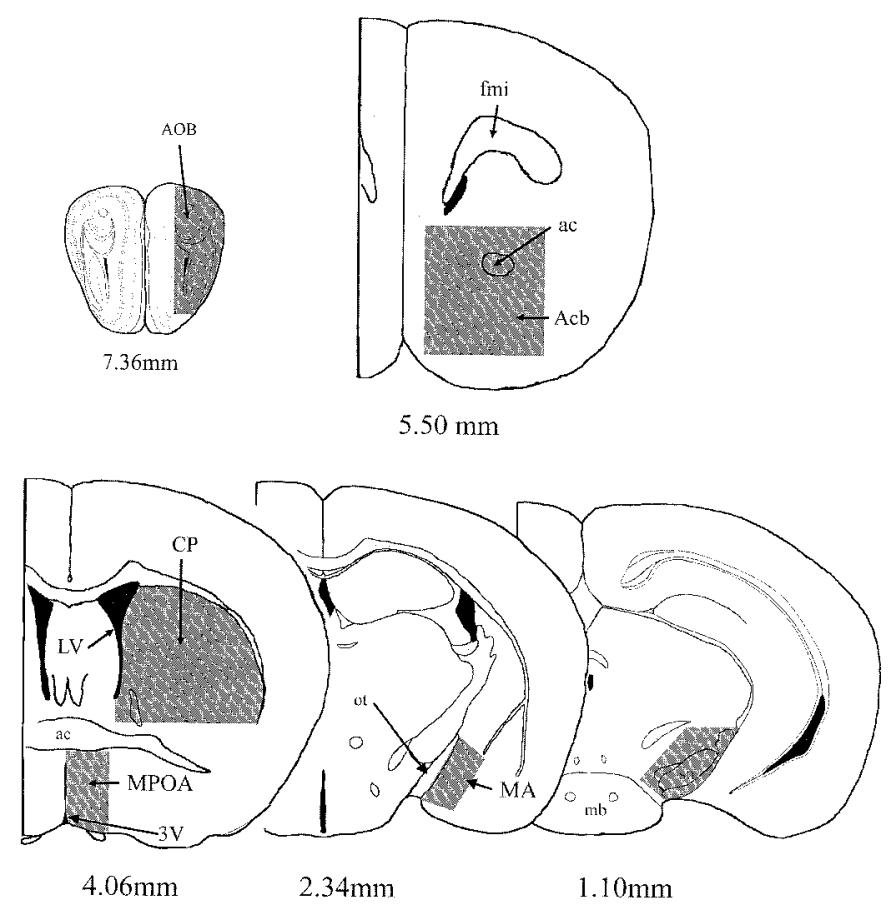

Figure 1. Camera lucida drawings showing the brain areas that were collected for HPLC quantification of catecholamine levels. The gray areas represent the boundaries of the tissue sample cut from a $200 \mu \mathrm{m}$ section. The stereotaxic coordinates listed are from Franklin and Paxinos (1997). $a c$, Anterior commissure; $A c b$, nucleus accumbens; $A O B$, accessory olfactory bulb; $C P$, caudate putamen; $f m i$, forceps minor corpus callosum; $L V$, lateral ventricle; $M A$, medial amygdala; $m b$, mammillary body; $M P O A$, medial preoptic area; ot, optic tract; sn, substantia nigra; $3 V$, third ventricle.

dissected using readily identifiable landmarks based on Franklin and Paxinos (1997) (Fig. 1).

HPLC. The brain tissue was thawed on ice with $200 \mu \mathrm{l}$ of buffer. Tissue was sonicated and centrifuged, and the supernatant was filtered using a $0.2 \mu \mathrm{m}$ microspin filter. The supernatant was kept on ice for $24 \mathrm{hr}$ until the sample was run through the HPLC column. During this time, no significant reduction was noted in the peak values for control samples run immediately after filtration and for control samples run $24 \mathrm{hr}$ after being filtered.

The buffer was $75 \mathrm{~mm}, \mathrm{pH} 3.00$, phosphate with $1.7 \mathrm{~mm}$ octanesulfonic acid, $100 \mathrm{ul} / 1$ triethylamine, $25 \mu \mathrm{M}$ EDTA, and $6 \%$ acetonitrile. The chromatography column was a Varian-Rainin Dynamax (R0080200E3), $3 \mathrm{U}, 100 \mathrm{~A}, 10 \mathrm{~cm}$ with guard cartridge. We used a flow rate of 1.0 $\mathrm{ml} / \mathrm{min}$. Our chromatography system was a Beckman 128 solvent module controlled by Beckman System Gold software with an ESA Coulochem II detector and a 5011 electrochemical detector with voltages set at $350 \mathrm{mV}$ (conditioning) $\mathrm{E} 1$ at $-70 \mathrm{mV}$ and $\mathrm{E} 2$ at $250 \mathrm{mV}$ (detection). The data were collected and analyzed by System Gold software. The samples were kept at $4^{\circ} \mathrm{C}$, and $20 \mu \mathrm{l}$ injections were made with a Jasco AS-950-10 autoinjector.

Statistics and analysis. The percentage of animals showing masculine sexual behavior was compared among groups using $\chi^{2}$ and Fisher's exact probability tests. The data recorded from animals that displayed sexual behavior was compared using one-way ANOVA followed by StudentNewman-Keuls post hoc comparisons. In cases in which the data failed, the normality test ANOVA on ranks was conducted followed by MannWhitney $U$ tests where appropriate. Social preference and HPLC data were analyzed by two-way ANOVA followed by Student-Newman-Keuls post hoc comparisons.

\section{RESULTS}

\section{Masculine sexual behavior}

In both males and females expression of sexual behavior varied with genotype and drug treatment $(p<0.05$ at least for each 


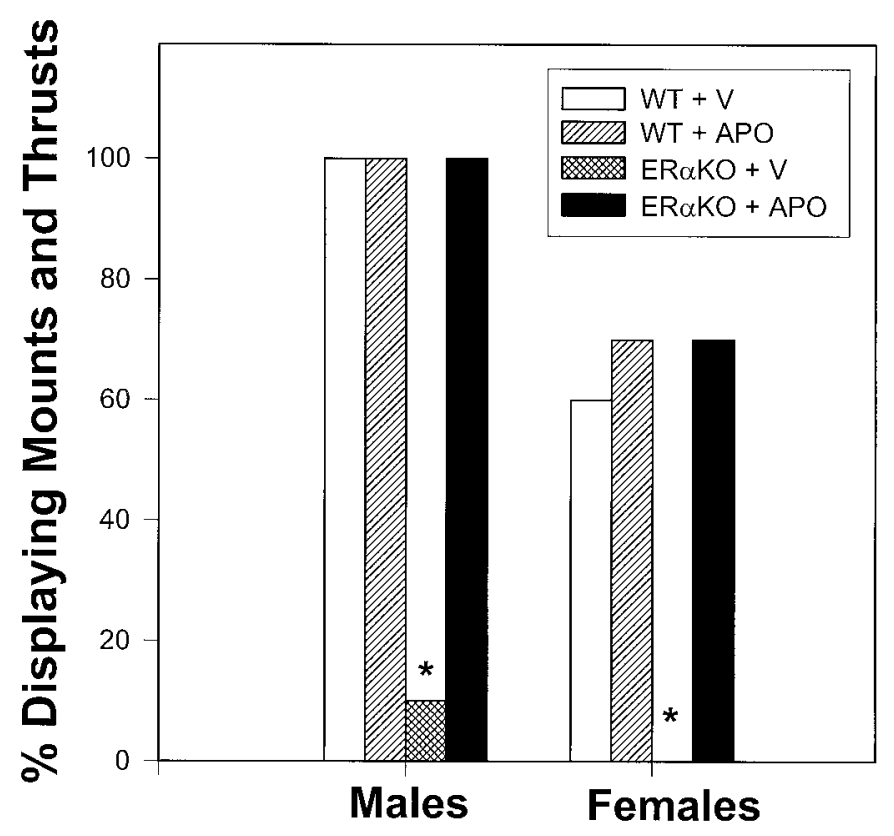

Figure 2. The percentage of wild-type (WT) and estrogen receptor $\alpha$ knock-out $(E R \alpha K O)$ mice treated with either vehicle $(V)$ or apomorphine $(A P O)$ showing mounting and thrusting behavior toward a receptive female. *Significantly lower than the other groups $p<0.05$.

comparison). As shown in Figure 2, the majority of wild-type males mounted, performed pelvic thrusts, and intromitted regardless of drug treatment. In addition, nearly all wild-type males ejaculated whereas none of the vehicle-treated ER $\alpha \mathrm{KO}$ males intromitted or ejaculated. All the $\mathrm{ER} \alpha \mathrm{KO}$ males given apomorphine mounted, thrusted, and intromitted with stimulus females (Fig. 2). Fifty percent of the ER $\alpha$ KOs treated with APO ejaculated.

Similar results were noted in females (Fig. 2). There was a significant difference in the frequency of females that mounted other females and thrusted during their mounts, and the frequency varied with genotype and drug treatment $(p<0.05$ at least). None of the $\mathrm{ER} \alpha \mathrm{KO}$ females treated with vehicle mounted or displayed thrusts. In the APO-treated ER $\alpha \mathrm{KO}$ group, $70 \%$ of the females mounted and thrusted. This rate was comparable to that noted in wild-type females (Fig. 2).

Behavior of males that engaged in sexual activity was examined. No differences between numbers of mounts, mounts with thrusts, or mounts with intromissions or the latencies to perform these behaviors were noted (Table 1). This finding shows that wild-type males were not adversely affected by APO treatment and that $\mathrm{ER} \alpha \mathrm{KO}$ males treated with APO did not differ in the display of their sexual behavior as compared with wild-type.

Females that displayed mount bouts and thrusts were also basically similar in all measures, regardless of genotype and drug treatment (Table 1). The only exception was in total number of mounts displayed $\left(F_{(2,19)}=5.32 ; p<0.02\right)$. ER $\alpha$ KO females treated with APO mounted significantly more than wild-type females that received either vehicle or APO treatment $(p<$ $0.05)$.

\section{Social preference}

The amount of time males spent sniffing the anesthetized stimulus animals varied with genotype and treatment. Time spent sniffing the stimulus female varied with genotype $\left(F_{(1,39)}=17.7\right.$; $p<0.0003)$, drug treatment $\left(F_{(1,39)}=4.4 ; p<0.05\right)$, and there was a significant interaction between the factors $\left(F_{(1,39)}=15.5\right.$; $p<0.0005)$. The ER $\alpha \mathrm{KO}$ vehicle-treated males were responsible for these effects; they spent less than one-third the amount of time sniffing females as compared to males in the other three groups $(p<0.05$; Fig. 3). A similar pattern was seen for time spent sniffing the stimulus male (main effect of genotype and an interaction; $F_{(1,39)}=5.95 ; p<0.02$ for both). The difference between times spent sniffing a female versus a male was similar as well (main effect of genotype and an interaction; $F_{(1,39)}=11.5,9.9$ respectively; $p<0.004$ at least). None of the other measures were significant; these included time spent in the compartment containing the male versus the female and the number of visits to each compartment.

Females did not exhibit social preferences (Fig. 4). There was a trend for $\mathrm{ER} \alpha \mathrm{KO}$ females that received vehicle to spend more time sniffing the stimulus females than the subjects in the other three groups $\left(F_{(1,38)}=3.39 ; p=0.074\right)$.

\section{HPLC}

In many of the forebrain regions examined we noted a significant effect of sex, but not of genotype, and no interaction between the two on catecholamine and catecholamine metabolite levels (Table 2 contains data for the AOB, MPOA, and striatum). Sex differences were always in the direction of higher levels of catecholamines in male brains than in female brains. All of the areas we examined, not all of which are listed on Table 2, had significant sex differences in DA ( $p<0.03$ at least for each). In addition dopamine was elevated in male brains relative to females in four of these six regions, including the MPOA, MA, nucleus accumbens, and the substantia nigra ( $p<0.05$ at least). In the MA and AOB significant sex differences were noted in epinephrine $(E)$, homovanillic acid (HVA), and 5-HT content ( $p<0.05$ at least). Finally in the substantia nigra males had significantly more norepinephrine $(\mathrm{NE})$ than females $(p<0.05)$. In the striatum, there were significant effects of sex, genotype, and an interaction between sex and genotype for DA $\left(F_{(1,21)}=9.78,33.0,54.34 ; p<\right.$ 0.05 at least). Genotype also affected NE content, and there was a significant interaction between sex and genotype $\left(F_{(1,21)}=4.50\right.$, 6.38; $p<0.04$ at least). Finally HVA content was affected by genotype $\left(F_{(1,21)}=5.18 ; p<0.04\right)$. All these effects in the striatum can be attributed to $\mathrm{ER} \alpha \mathrm{KO}$ males, which had significantly higher catecholamine content than mice in all other groups.

\section{DISCUSSION}

The present results replicate our past findings that gonadectomized, T-treated male and female $\mathrm{ER} \alpha \mathrm{KO}$ mice fail to exhibit normal masculine sexual behavior as compared with similarly treated wild-type littermates (Wersinger et al., 1997). However, here we show that normal masculine behavior can be elicited in adulthood if $\mathrm{T}$ is supplemented by APO. A similar result was obtained for chemoinvestigatory behavior in males. We have shown that $\mathrm{ER} \alpha \mathrm{KO}$ males fail to preferentially investigate anesthetized $\mathrm{E}_{2}$-treated stimulus females (Wersinger and Rissman, 2000). In the present study the same effect was noted, but APO treatment corrected this deficiency in ER $\alpha \mathrm{KO}$ males. Chemoinvestigatory behavior is displayed by wild-type and $\operatorname{ER} \alpha \mathrm{KO}$ females, but they do not have social preferences. Moreover, unlike masculine sexual behavior, female-directed chemoinvestigation was not activated by $\mathrm{T}$ alone or $\mathrm{T}$ supplemented with APO in females. Taken together our results show that masculine sexual 


\begin{tabular}{|c|c|c|c|c|c|c|c|}
\hline $\begin{array}{l}\text { Sex Genotype } \\
\text { Treatment }\end{array}$ & $\begin{array}{l}\text { Latency to } \\
\text { mount (min) }\end{array}$ & $\begin{array}{l}\text { Latency to } \\
\text { thrust (min) }\end{array}$ & $\begin{array}{l}\text { Number of mount } \\
\text { bouts }\end{array}$ & $\begin{array}{l}\text { Number of bouts } \\
\text { with thrusts }\end{array}$ & $\begin{array}{l}\text { Latency to } \\
\text { intromit (min) }\end{array}$ & $\begin{array}{l}\text { Latency to } \\
\text { ejaculate (min) }\end{array}$ & $\begin{array}{l}\text { Intro. to } \\
\text { ejaculation } \\
\text { interval (min) }\end{array}$ \\
\hline \multicolumn{8}{|l|}{ Male WT } \\
\hline Vehicle & $25.5 \pm 3.06$ & $38.9 \pm 6.38(10)$ & $13.1 \pm 2.83(10)$ & $10.3 \pm 2.01(10)$ & $57.7 \pm 6.24(10)$ & $77.1 \pm 2.82(7)$ & $26.14 \pm 6.45(7)$ \\
\hline \multicolumn{8}{|l|}{ Male WT } \\
\hline APO & $27.0 \pm 3.71$ & $48.8 \pm 3.73(10)$ & $11.0 \pm 1.95(10)$ & $11.1 \pm 2.24(10)$ & $71.9 \pm 5.06(10)$ & $73.2 \pm 3.4$ & $9.67 \pm 3.32(6)$ \\
\hline \multicolumn{8}{|l|}{ Male ER $\alpha \mathrm{KO}$} \\
\hline $\begin{array}{c}\text { APO } \\
\text { Female WT }\end{array}$ & $25.9 \pm 3.91$ & $41.2 \pm 5.13(10)$ & $15.8 \pm 3.05(10)$ & $10.9 \pm 2.21(10)$ & $70.0 \pm 3.97(10)$ & $77.0 \pm 2.39(5)$ & $10.8 \pm 4.45(5)$ \\
\hline $\begin{array}{c}\text { Vehicle } \\
\text { Female WT }\end{array}$ & $55.0 \pm 10.66(6)$ & $58.2 \pm 8.72(6)$ & $5.0 \pm 1.43(6)$ & $4.83 \pm 1.25(6)$ & NA & NA & NA \\
\hline $\begin{array}{r}\text { APO } \\
\text { Female }\end{array}$ & $56.3 \pm 8.13$ & $65.7 \pm 9.23(7)$ & $5.57 \pm 1.39(7)$ & $6.0 \pm 1.53(7)$ & NA & NA & NA \\
\hline $\begin{array}{l}\mathrm{ER} \alpha \mathrm{KO} \\
\mathrm{APO}\end{array}$ & $60.4 \pm 7.04$ & $71.3 \pm 7.82(7)$ & $10.0^{*} \pm 0.65(7)$ & $4.14 \pm 0.86(7)$ & NA & NA & NA \\
\hline
\end{tabular}

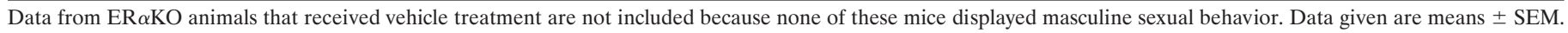
Numbers of mice per group is given in parentheses.

*Significant genotype difference within same sex. NA, Not applicable; WT, wild-type mice; ER $\alpha$ KO, estrogen receptor $\alpha$ knock-out littermates.

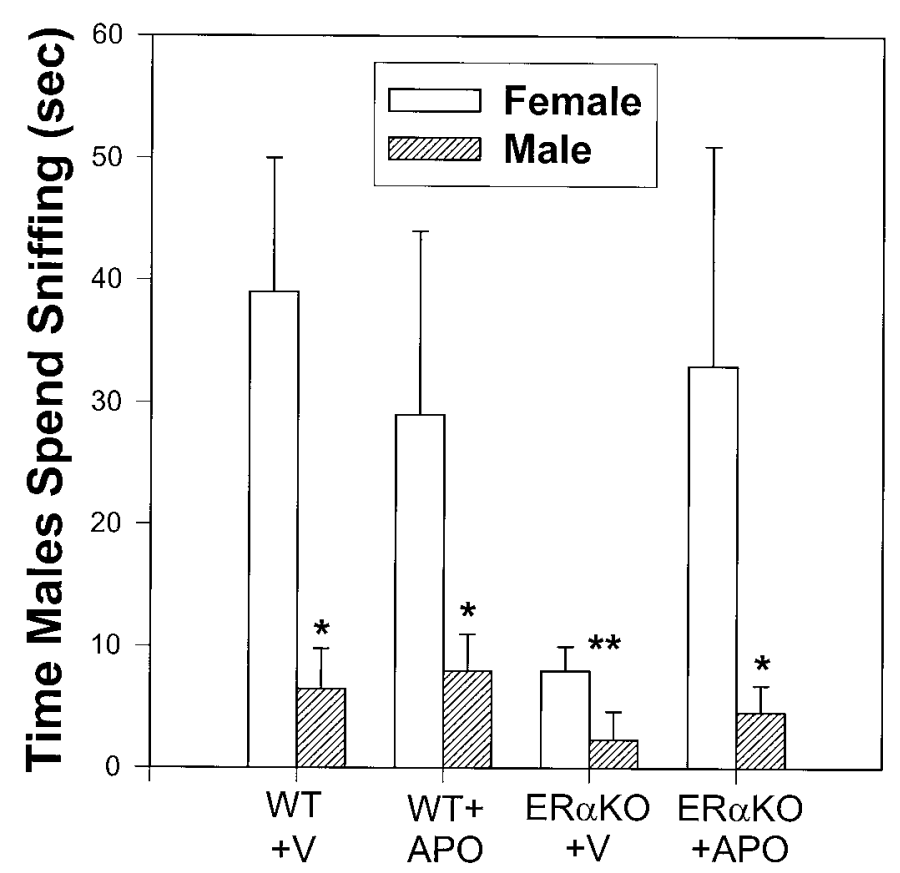

Genotype and Treatment

Figure 3. The mean amount of time in seconds (+SEM) male wild-type $(W T)$ and estrogen receptor $\alpha$ knock-out $(E R \alpha K O)$ mice treated with either vehicle $(V)$ or apomorphine $(A P O)$ spent engaged in chemoinvestigation of an anesthetized estrogen-treated female or an anesthetized gonad-intact male. *Significantly less time spent investigating the male versus the female, $p<0.05$. ${ }^{*} \mathrm{ER} \alpha \mathrm{KO}$ vehicle-treatment animals spent significantly less total time $(p<0.05)$ engaged in chemoinvestigation than mice in the other three treatment groups.

behavior is not particularly sexually dimorphic in wild-type mice. Aspects of male copulatory behavior that do not depend on a penis can be activated in females by elevated levels of T. Moreover, this male-typical copulatory performance is not dependent on the $\mathrm{ER} \alpha$ in mice of either sex. In contrast, female-directed chemoinvestigation is sexually dimorphic in mice, and increasing

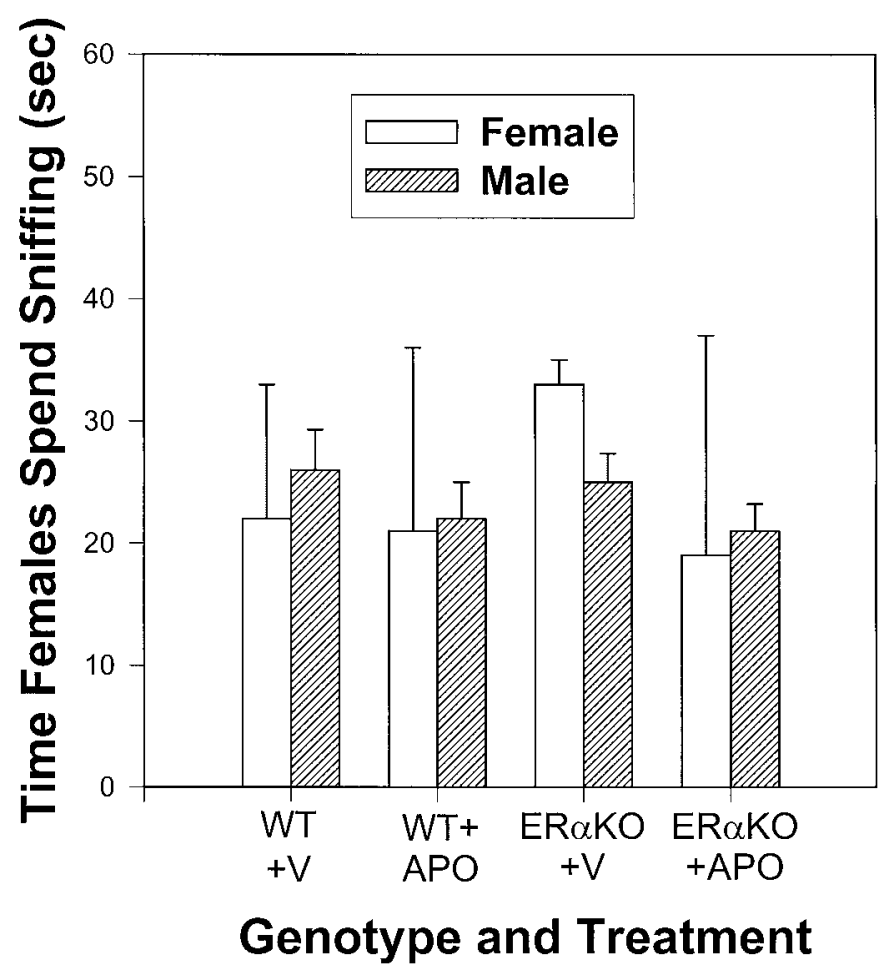

Figure 4. The mean amount of time in seconds (+SEM) female wildtype $(W T)$ and estrogen receptor $\alpha$ knock-out $(E R \alpha K O)$ mice treated with either vehicle $(V)$ or apomorphine $(A P O)$ spent engaged in chemoinvestigation of an anesthetized estrogen-treated female or an anesthetized gonad-intact male.

levels of $\mathrm{T}$ did not facilitate display of this behavior in females. Although APO can activate this behavior in male ER $\alpha \mathrm{KO}$, drug treatment had no effect on preference behavior in female mice of either genotype.

The HPLC data show that neural content of several catecholamines and their metabolites is largely similar between wild-type and $\mathrm{ER} \alpha \mathrm{KO}$ mice. However, for masculine sex behavior in rats it is critical that DA is not only present, but is released 


\begin{tabular}{|c|c|c|c|c|c|c|c|c|}
\hline Region & Sex and genotype & $\begin{array}{l}\mathrm{DA}^{a, e} \\
(\mathrm{ng} / \mathrm{mg})\end{array}$ & $\begin{array}{l}\mathrm{DOPA}^{a} \\
(\mathrm{ng} / \mathrm{mg})\end{array}$ & $\begin{array}{l}\text { DOPAC } \\
(\mathrm{ng} / \mathrm{mg})\end{array}$ & $\begin{array}{l}\mathrm{HVA}^{b, f} \\
(\mathrm{ng} / \mathrm{mg})\end{array}$ & $\begin{array}{l}\mathrm{NE}^{d} \\
(\mathrm{ng} / \mathrm{mg})\end{array}$ & $\begin{array}{l}E^{b} \\
(\mathrm{ng} / \mathrm{mg})\end{array}$ & $\begin{array}{l}5-\mathrm{HT}^{b} \\
(\mathrm{ng} / \mathrm{mg})\end{array}$ \\
\hline \multirow[t]{5}{*}{$\mathrm{AOB}$} & Male (6) WT & $148.6 \pm 67.3$ & $83.8 \pm 13.2$ & $3.6 \pm 2.02$ & $94.8 \pm 61.2$ & $95.3 \pm 26.53$ & $150.7 \pm 49.9$ & $132.7 \pm 3.29$ \\
\hline & Male (6) ER $\alpha \mathrm{KO}$ & $214.6 \pm 89.7$ & $93.1 \pm 10.1$ & $1.65 \pm 2.77$ & $251.4 \pm 97.9$ & $106.4 \pm 32.26$ & $191.9 \pm 60.5$ & $146.5 \pm 20.07$ \\
\hline & Female (5) WT & $40.5 \pm 13.0$ & $52.5 \pm 15.8$ & $11.9 \pm 5.5$ & $51.2 \pm 10.3$ & $77.0 \pm 12.2$ & $15.2 \pm 4.2$ & $70.9 \pm 25.1$ \\
\hline & Female (5) & & & & & & & \\
\hline & $\mathrm{ER} \alpha \mathrm{KO}$ & $41.7 \pm 5.2$ & $28.2 \pm 16.9$ & $7.5 \pm 3.0$ & $88.13 \pm 30.7$ & $85.00 \pm 17.5$ & $15.7 \pm 5.2$ & $85.5 \pm 19.2$ \\
\hline \multirow[t]{5}{*}{ MPOA } & Male (6) WT & $407.3 \pm 65.9$ & $103.0 \pm 8.1$ & $1.4 \pm 0.9$ & $206.9 \pm 21.4$ & $310.5 \pm 14.7$ & $111.0 \pm 45.0$ & $191.5 \pm 37.7$ \\
\hline & Male (6) $\mathrm{ER} \alpha \mathrm{KO}$ & $476.6 \pm 88.0$ & $118.5 \pm 16.4$ & $1.5 \pm 2.0$ & $118.8 \pm 42.2$ & $246.9 \pm 10.5$ & $45.8 \pm 12.4$ & $269.8 \pm 175.1$ \\
\hline & Female (5) WT & $202.3 \pm 69.3$ & $46.3 \pm 12.9$ & $9.4 \pm 3.9$ & $229.3 \pm 46.3$ & $236.8 \pm 44.5$ & $80.9 \pm 22.8$ & $128.5 \pm 26.0$ \\
\hline & Female (5) & & & & & & & \\
\hline & $\mathrm{ER} \alpha \mathrm{KO}$ & $252.9 \pm 93.7$ & $32.3 \pm 17.5$ & $4.5 \pm 1.1$ & $239.3 \pm 35.4$ & $214.9 \pm 39.6$ & $74.4 \pm 19.9$ & $166.8 \pm 43.6$ \\
\hline \multirow[t]{5}{*}{ ST } & Male (6) WT & $438.3 \pm 190.1$ & $68.5 \pm 17.5$ & $4.51 \pm 2.35$ & $243.3 \pm 99.8$ & $64.6 \pm 21.1$ & $76.1 \pm 34.0$ & $128.0 \pm 4.3$ \\
\hline & Male (6) ER $\alpha \mathrm{KO}$ & $1015.3 \pm 71.1$ & $89.7 \pm 13.9$ & $30.7 \pm 27.5$ & $647.7 \pm 226.6$ & $248.3 \pm 75.9$ & $319.3 \pm 135.9$ & $98.8 \pm 17.7$ \\
\hline & Female (5) WT & $213.7 \pm 63.7$ & $54.0 \pm 15.4$ & $7.9 \pm 1.3$ & $346.2 \pm 61.7$ & $91.6 \pm 7.1$ & $71.9 \pm 21.4$ & $116.1 \pm 37.3$ \\
\hline & Female (5) & & & & & & & \\
\hline & $\mathrm{ER} \alpha \mathrm{KO}$ & $207.7 \pm 97.6$ & $35.0 \pm 19.4$ & $7.4 \pm 1.2$ & $382.0 \pm 49.7$ & $68.7 \pm 8.4$ & $164.6 \pm 22.8$ & $72.3 \pm 16.5$ \\
\hline
\end{tabular}

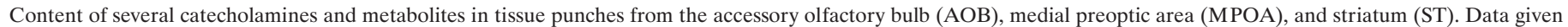
are means \pm SEM. Numbers of brains per treatment group is given in parentheses.

${ }^{a}$ Significant sex difference in all regions.

${ }^{b}$ Significant sex difference in the AOB.

${ }^{c}$ Significant sex difference in the MPOA.

${ }^{d}$ Significant genotype and genotype by sex interaction in the ST.

${ }^{e}$ Significant sex, genotype and sex by genotype interaction in the ST.

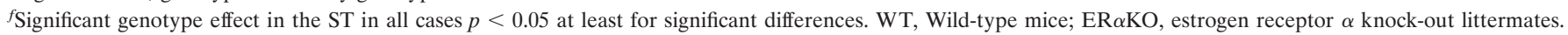

into the extracellular environment where it can bind its postsynaptic receptors (Hull et al., 1995, 1997). The question of DA availability in synapses in the $\mathrm{ER} \alpha \mathrm{KO}$ brain still needs to be addressed. We found sex differences in catecholamine levels in many regions (Table 2). Wild-type females, despite having lower levels of catecholamines than males, expressed masculine sexual behavior, demonstrating that neural catecholamine content is sufficient in females for the expression of these behaviors. All mice in our study received equivalent $\mathrm{T}$ treatment, thus, differences in steroid levels do not explain the sex differences in catecholamine content. These sex differences could be caused by differential sensitivity to adult $\mathrm{T}$. Regardless of the nature of the sex difference, it is clear that its development does not rely on $\operatorname{ER} \alpha$. The striatum was the only region in which we detected an effect of genotype on catecholamine content. The striatum has been implicated in male sexual behavior. In male rats, extracellular dopamine increased in the striatum after copulation (Damsma et al., 1992). Thus, it is possible that ER $\alpha \mathrm{KO}$ males, like castrated rats (Hull et al., 1995) accumulate, but do not release DA in the brain. This inability to release DA may contribute to the failure of $\operatorname{ER} \alpha \mathrm{KO}$ to display masculine sexual behaviors.

Many lines of evidence show that dopamine is involved in male sexual behavior. Sexually experienced, long-term castrated rats can display copulatory behavior, including ejaculation in some cases, after treatment with APO (Scaletta and Hull, 1990). More reliable sexual behavior is seen when castrated male rats are treated with subthreshold doses of $\mathrm{T}$ and APO is provided (Hull et al., 1997). Dopamine-deficient knock-out mice require both $\mathrm{T}$ and dopamine to display sexual behavior (Szczypka et al., 1998). In addition, DA antagonists impair copulatory behavior (Pehek et al., 1988) in rats. Hull et al. (1997) have proposed a pathway in which $\mathrm{T}$ upregulates nitric oxide synthase (NOS) in the MPOA, NOS in turn enhances DA release. Immunoreactivity for NOS neurons in the MPOA is enhanced in male rats exposed to females (Dominguez and Hull, 1999). Castration leads to fewer NOS-IR cells in the MPOA and bed nucleus of the stria terminalis (Du and Hull, 1999). Pilot data collected in our lab show that $\mathrm{ER} \alpha \mathrm{KO}$ males have fewer NOS-ir cells in the MPOA than wild-type males (J. Perkins and E. Rissman, unpublished observations). These data suggest that $\mathrm{T}$ regulates NOS via actions on ER $\alpha$. Data collected on endothelial NO production supports this hypothesis (Shaul, 1999). Moreover, basal release of endothelium-derived NO is significantly lower in aorta tissue from $\mathrm{ER} \alpha \mathrm{KO}$ as compared to wild-type male mice (Rubanyi et al., 1997). Thus, ER $\alpha$ may act during development and/or adulthood as a modulator of NOS activity in brain.

Another link between dopamine, steroid receptors, and sexual behavior is the progesterone receptor (PR). Interestingly estrogen can induce PR (mRNA and protein) in the female ER $\alpha \mathrm{KO}$ brain (Shughrue et al., 1997; Moffatt et al., 1998). In the caudal ventromedial hypothalamus, the numbers of estrogen-induced PR-IR cells are only $50 \%$ lower than that seen in wild-type females (Moffatt et al., 1998). In female rats and mice DA can stimulate sexual behavior by activating the PR in a ligandindependent manner (Mani et al., 1994, 1996). Although generally associated with female sexual behavior, several lines of evidence have shown that the PR may be involved in male sexual behavior. For example, on their first behavior test, male PR knock-out mice display reduced levels of masculine sexual behavior, compared with wild-type males (Phelps et al., 1998). If similar mechanisms are in place in males, it is possible that APO may act on PR in the MPOA. Perhaps in the ER $\alpha \mathrm{KO}$ and wild-type mouse, APO activates unoccupied PR and this stimulates mas- 
culine sexual behavior, given the correct hormone and testing conditions.

The involvement of dopamine in differentiation of sex differences has been examined in two contexts. Several researchers have treated pregnant rats, or their pups, with DA agonists or antagonists and tested the offspring for masculine sexual behavior (Hull et al., 1984; Gonzales and Leret, 1992). Dopamine agonists and antagonists are both able to demasculinize males (Hull et al., 1984; Gonzales and Leret, 1992). Thus, the interpretation of these data has to be that some optimal level of DA is required during development, either too much or too little can demasculinize genetic males. Reisert and Pilgrim (1991) have extensively studied sex differences in dopaminergic cells in vitro. In mouse and rat, fetal dopaminergic neurons from midbrain or hypothalamus are removed before gonad differentiation. After several days in culture sex differences develop, either in the absence of steroids, or in the presence of equivalent titers of steroid (Beyer et al., 1991). Thus, a possibility for the effects of APO in $\mathrm{ER} \alpha \mathrm{KO}$ mice is that dopamine acts on a pathway that is not influenced by the lack of $\mathrm{ER} \alpha$ during development.

Dopamine can stimulate copulatory behavior in male and female mice that lack the $\operatorname{ER} \alpha$. Thus, $\operatorname{ER} \alpha$ is not required for neural development of masculine sexual behavior circuits in mice. This idea is a radical departure from the dogma, however, the organizational/activational hypothesis does not explain all sexual dimorphic behaviors (Arnold, 1996). Moreover, although strain differences exist, mice in general do not have as pronounced sexual dimorphisms in brain as do other rodents (Brown et al., 1999). Yet, social preference, as measured by chemoinvestigation of females, is more sexually dimorphic in mice than is masculine copulatory behavior. The accessory olfactory system is sexually dimorphic in rats (Guillamon and Segovia, 1997). Exposure to steroid hormones controls the development of this dimorphism, which can be reversed by steroids during the critical period (Collado et al., 1998). The neural projection pathway from the AOB includes the MA, bed nucleus of the stria terminalis, and the hypothalamus. One terminal region, the anterioventral periventricular region is sexually dimorphic, and this dimorphism is nearly reversed in male ER $\alpha \mathrm{KO}$ brains (Simerly et al., 1997). In ongoing studies we are examining sex differences in neural pathways that underlie perception of chemosensory cues in mice.

Our data compliment those collected by others using the $\mathrm{ER} \alpha \mathrm{KO}$ model. Estrogenic responses can be elicited in these animals under certain conditions (Das et al., 1997; Shughrue et al., 1997; Moffatt et al., 1998; Singh et al., 2000). For example, estradiol can phosphorylate extracellular signal-regulated kinase 1 in brains of ER $\alpha \mathrm{KO}$ females (Singh et al., 2000). It is possible that an estrogen-responsive protein other than ER mediates these estrogenic effects. Alternatively, the disrupted $\operatorname{ER} \alpha$ gene is transcribed to form a truncated, presumable inactive, protein (Couse et al., 1995). Our finding elaborates on data collected by others in showing that the $\operatorname{ER} \alpha$ deficit can be overridden by a nonestrogenic mechanism.

\section{REFERENCES}

Abdelgadir SE, Resko JA, Ojeda SR, Lephart ED, McPhaul MJ, Roselli CE (1994) Androgens regulate aromatase cytochrome P450 messenger ribonucleic acid in rat brain. Endocrinology 135:395-401.

Arnold AP (1996) Genetically triggered sexual differentiation of brain and behavior. Horm Behav 30:495-505.

Baum MJ (1979) Differentiation of coital behavior in mammals: a comparative analysis. Neurosci Biobehav Rev 3:265-284.
Beyer C, Pilgrim C, Reisert I (1991) Dopamine content and metabolism in mesencephalic and diencephalic cell cultures: sex differences and effects of sex steroids. J Neurosci 11:1325-1333.

Brown AE, Mani S, Tobet SA (1999) The preoptic area/anterior hypothalamus of different strains of mice: sex differences and development. Dev Brain Res 115:171-182.

Collado P, Segovia S, Guillamon A (1998) Development of sex differences in the bed nucleus of the accessory olfactory tract in the rat. Dev Brain Res 109:99-108.

Couse JF, Curtis SW, Washburn TF, Lindzey J, Golding TS, Lubahn DB, Smithies O, Korach KS (1995) Analysis of transcription and estrogen insensitivity in the female mouse after targeted disruption of the estrogen receptor gene. Mol Endocrinol 9:1441-1454.

Crews D (1983) Control of male sexual behaviour in the Canadian red-sided garter snake. In: Hormones and behavior in higher vertebrates (Balthazart J, Prove E, Gilles R, eds), pp 398-406. Berlin: Springer.

Damsma G, Pfaus JG, Wenkstern D, Phillips AG, Fibiger HC (1992) Sexual behavior increases dopamine transmission in the nucleus accumbens and striatum of male rats: comparison with novelty and locomotion. Behav Neurosci 106:181-191.

Das SK, Taylor JA, Korach KS, Paria BC, Dey SK, Lubhan DB (1997) Estrogenic responses in estrogen receptor- $\alpha$ deficient mice reveal a distinct estrogen signaling pathway. Proc Natl Acad Sci USA 94:12786-12791.

Dominguez J, Hull EM (1999) Influence of olfactory exposure to a female rat on nitric oxide synthase in the MPOA of male rats. Poster presented at the Society for Behavioral Neuroendocrinology meeting, June, Charlottesville, VA.

Du J, Hull EM (1999) Effects of testosterone on neuronal nitric oxide synthase and tyrosine hydroxylase. Brain Res 836:90-98.

Franklin KBJ, Paxinos G (1997) The mouse brain in stereotaxic coordinates. San Diego: Academic.

Gonzales MI, Leret ML (1992) Neonatal catecholaminergic influence on behavior and sexual hormones. Physiol Behav 51:527-531.

Goy RW, McEwen BS (1980) Sexual differentiation of the brain. Cambridge, MA: MIT.

Guillamon A, Segovia S (1997) Sex differences in the vomeronasal system. Brain Res Bull 44:377-382.

Hull EM, Nishita JK, Bitran D, Dalterio S (1984) Perinatal dopaminerelated drugs demasculinize rats. Science 224:1011-1013.

Hull EM, Du J, Lorrain DS, Matuszewich L (1995) Extracellular dopamine in the medial preoptic area: implications for sexual motivation and hormonal control of copulation. J Neurosci 15:7465-7471.

Hull EM, Du J, Lorrain DS, Matuszewich L (1997) Testosterone, preoptic dopamine, and copulation in male rats. Brain Res Bull 44:327-333.

Kuiper GGJM, Enmark E, Pelto-Huikko M, Nilsson S, Gustafsson JA (1996) Cloning of a novel estrogen receptor expressed in rat prostate and ovary. Proc Natl Acad Sci USA 93:5925-5930.

Lubahn DB, Moyer JS, Golding TS, Couse JF, Korach KS, Smithies O (1993) Alteration of reproductive function but not prenatal sexual development after insertational disruption of the mouse estrogen receptor gene. Proc Natl Acad Sci USA 90:11162-11166.

Mani SK, Allen JM, Clark JH, Blaustein JD, O'Malley BW (1994) Convergent pathways for steroid hormone- and neurotransmitterinduced rat sexual behavior. Science 265:1246-1249.

Mani SK, Allen JM, Lydon JP, Mulac-Jericevic B, Blaustein JD, DeMayo FJ, Conneeley O, O'Malley BW (1996) Dopamine requires the unoccupied progesterone receptor to induce sexual behavior in mice. Mol Endocrinol 10:1728-1737.

McCarthy MM (1994) Molecular aspects of sexual differentiation of the rodent brain. Psychoneuroendocrinology 19:415-427.

Meisel RL, Sachs BD (1994) The physiology of male sexual behavior. In: The physiology of reproduction, Vol 2 (Knobil E, Neill JD, eds), pp 3-105. New York: Raven.

Moffatt CA, Rissman EF, Shupnik MA, Blaustein JD (1998) Induction of progestin receptors by estradiol in the forebrain of estrogen receptor- $\alpha$ gene-disrupted mice. J Neurosci 18:9556-9563.

Pehek EA, Warner RK, Bazzett TJ, Bitran D, Band LC, Eaton RC, Hull EM (1988) Microinjection of cis-flupenthixol, a dopamine antagonist, into the medial preoptic area impairs sexual behavior of male rats. Brain Res 443:70-76.

Phelps SM, Lydon JP, O'Malley BW, Crews D (1998) Regulation of male 
sexual behavior by progesterone receptor, sexual experience, and androgen. Horm Behav 34:294-302.

Reisert I, Pilgrim C (1991) Sexual differentiation of monoaminergic neurons -genetic or epigenetic. Trends Neurosci 14:468-473.

Rissman EF, Early AH, Taylor JA, Korach KS, Lubahn DB (1997) Estrogen receptors are essential for female sexual receptivity. Endocrinology 138:507-510.

Rubanyi GM, Freay AD, Kauser K, Sukovich D, Burton G, Lubahn DB, Couse JF, Curtis SW, Korach KS (1997) Vascular estrogen receptors and endothelium-derived nitric oxide production in the mouse aorta. J Clin Invest 99:2429-2437.

Scaletta LL, Hull EM (1990) Systemic or intracranial apomorphine increases copulation in long-term castrated male rats. Pharmacol Biochem Behav 37:471-475.

Shaul PW (1999) Rapid activation of endothelial nitric oxide synthase by estrogen. Steroids 64:28-34.

Shughrue PJ, Lubahn DB, Negro-Vilar A, Korach KS, Merchenthaler I (1997) Responses in the brain of estrogen receptor $\alpha$-disrupted mice. Proc Natl Acad Sci USA 94:11008-11012.

Simerly RB, Zee MC, Pendleton JW, Lubahn DB, Korach KS (1997) Estrogen receptor-dependent sexual differentiation of dopamine neurons in the preoptic region of the mouse. Proc Natl Acad Sci USA 94:14077-14082.

Singh M, Selalo G, Toran-Allerand CD (2000) Estrogen-induced activa- tion of the MAP kinase cascade in the cerebral cortex of estrogen receptor- $\alpha$ knockout (ERKO) mice. J Neurosci, in press.

Szczypka MS, Zhou QY, Palmiter RD (1998) Dopamine-stimulated sexual behavior is testosterone dependent in mice. Behav Neurosci 112:1229-1235.

Tobet SA, Fox TO. (1992) Sex differences in neuronal morphology influenced hormonally throughout life. In: Sexual differentiation: handbook of behavioral neurobiology, Vol 11 (Gerall AA, Moltz H, Ward IL, eds), pp 41-83. New York: Plenum.

Tremblay GB, Tremblay A, Copeland NG, Gilbert DJ, Jenkins NA, Labire F, Giguere V (1997) Cloning, chromosomal location, and functional analysis of the murine estrogen receptor beta. Mol Endocrinol 11:353-365.

Vagell ME, McGinnis MY (1997) The role of aromatization in the restoration of male rat reproductive behavior. J Neuroendocrinol 9:415-421.

Wersinger SR, Sannen K, Villalba C, Lubahn DB, Rissman EFR, DeVries GJ (1997) Masculine sexual behavior is disrupted in male and female mice lacking a functional estrogen receptor $\alpha$ gene. Horm Behav 32:176-183.

Wersinger SR, Rissman EF (2000) Oestrogen receptor $\alpha$ is essential for female-directed chemo-investigatory behaviour but is not required for the pheromone-induced luteinizing hormone surge in male mice. J Neuroendocrinol 12:103-110. 